\title{
Net losses pose extinction risk for porpoise
}

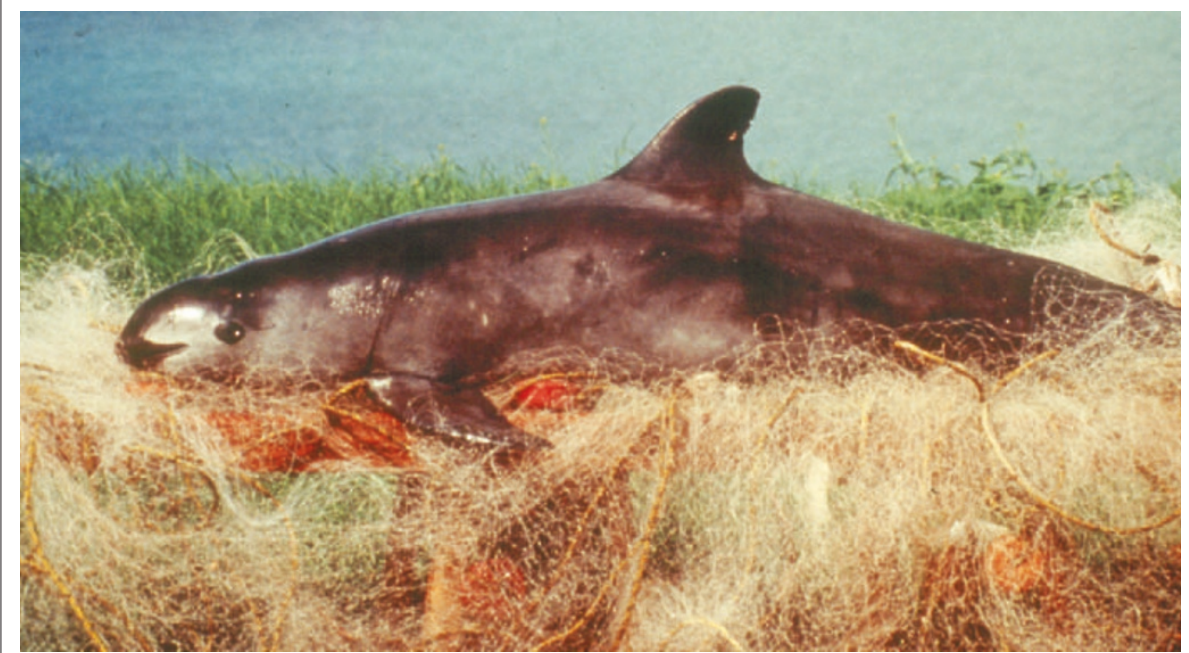

In peril: at least six vaquita have died this year after being accidentally caught in fishing nets.

Rex Dalton, San Diego

One of the world's most endangered marine mammals is dying in fishing nets at an alarming rate in the Gulf of California off Mexico, prompting fears that the species could soon be extinct.

Mexican scientists have confirmed that at least six of the porpoises, called vaquita (Phocoena sinus), have died in nets in the past six months. This level of reported deaths by fishermen is unprecedented, scientists say and many more may actually be dying.

"At this rate, the species will not survive very long," says marine mammalogist Lorenzo Rojas Bracho, coordinator of Mexico's National Marine Mammal Programme in Ensenada.
The vaquita is now only found in the Gulf of California. Its population has dwindled to less than 600 animals after years of being accidentally snagged in the nets of large trawlers and small boats called pangas as they fish for shrimp and fish. The porpoises have been considered critically endangered by Mexican and international agencies for a decade.

In 1993 the Mexican government established a reserve area, including a no-fishing zone, in the upper Gulf, where fresh water trickling into the Gulf from the Colorado River is thought to provide ideal conditions for fish that the vaquita feeds on. But Mexican officials and scientists say that commercial shrimp trawlers and pangas are continuing to fish the reserve illegally.

Fishing-industry officials and some members of the Mexican government blame the disappearance of the vaquita on USowned dams in the Colorado River, which limits the amount of fresh water flowing into the estuary and may cut down the vaquita's food supply. But marine scientists who monitor the vaquita are unanimous that fishing nets are the main culprit. "Fishing clearly is the greatest threat," says Jay Barlow, a marine mammalogist at the Southwest Fisheries Science Center in La Jolla and a member of the recovery team.

Environmental groups including The Nature Conservancy, the WWF and Conservation International have devised a viable plan to save the porpoises, says Exequiel Ezcurra, president of Mexico's National Institute of Ecology in Mexico City. They propose that the Mexican government divert US\$50 million, currently used to subsidize fuel prices for the shrimp trawling industry, to instead purchase trawlers and decommission them. This would leave more fish for the panga fishermen, who would be encouraged to use fish traps and other methods that do not endanger the vaquita as gill nets do.

Ezcurra says the plan has not been implemented because the trawling industry won't give up its ships or make long-term commitments to halt fishing in the area. Industry groups did not respond to interview requests from Nature.

"I personally feel that the plan is the only ray of hope for the vaquita," says Ezcurra. "I am pushing for it very strongly."

\section{Critics blast 'premature' paper on adult stem cells}

Quirin Schiermeier and Martin Leeb, Munich A stem-cell paper published last month in an online physics journal has created quite a stir. The paper, which was described as a "breakthrough" in adult stem-cell technology at a public announcement in Germany, is scientifically premature, experts say, and may lead to a surge in protests against research using embryonic lines.

In the current issue of Applied Physics A (doi:10.1007/s00339-004-2816-6; 2004) — an online journal published by Springer that normally reports materials-science research - a team of German biologists describes a technique for isolating stem cells from the pancreas of adult humans and rats. In culture, the cells differentiated into multiple cell lineages, such as brain and muscle cells, the team reports. If confirmed, the discovery would allow researchers often to use stem cells from adults instead of from embryos - a particularly controversial source in Germany. At a press conference in Berlin on 28 May, politicians of the Christian Democrats and Social Democrats referred to the study as "groundbreaking". Wolfgang Wodarg, health spokesman for the Social Democrats, said it was a blow to supporters of research involving human embryonic stem cells.

But leading stem-cell researchers rebuked the team and its host institutions - the University of Lübeck and the Fraunhofer Institute for Biomedical Engineering (IBMT) in St Ingbert - for publishing premature results. They point out that the paper was accepted one day after it was submitted, without full peer review. The paper provides little evidence for many of its claims, says Hans Schöler, a stem-cell researcher at the University of Pennsylvania in Philadelphia.

Michael Stuke, editor-in-chief of Applied Physics A, says he took the advice of several experts before deciding to publish. "If I think that a topic is really hot and needs to be disseminated without the delay typical for major journals, I won't hesitate to invite biologists to publish in our journal," he says.

Publishing the data in an unreviewed physics journal was a "less-than-ideal solution”, admits Günter Fuhr, director of the IBMT, who supervised the study. But he backs their decision to inform the public of their results at an early stage. Requests from Nature to interview the lead author of the paper, Charli Kruse of the University of Lübeck, were deferred to Fuhr.

Others say the paper's high profile will strengthen opposition to embryonic stemcell research. "I am concerned that the whole field might suffer if news about alleged breakthroughs is spread in this way," says Oliver Brüstle, head of reconstructive neurobiology at the University of Bonn. 